\title{
複写される方へ
}

本誌に掲載された著作物を複写したい方は、（社）日本複写権センターと包括複写許諾契約を 締結されている企業の方でない限り、著作権から複写権等の行使の委託を受けている次の団体か ら許諾を受けて下さい。

干 107-0052 東京都港区赤坂 9-6-41 乃木坂ビル （中法）学術著作権協会 電話：03-3475-5618 FAX：03-3475-5619 E-mail : jaacc@mtd.biglobe.ne.jp 著作物の転載・翻訳のような複写以外の許諾は、直接本会へご連絡下さい。

アメリカ合衆国に抢ける複写については、次に連絡してください。

Copyright Clearance Center, Inc.

222 Rosewood Drive, Danvers, MA 01923 USA

Phone : +1-978-750-8400 FAX: +1-978-750-4744

\section{Notice about photocopying}

In order to photocopy any work from this publication, you or your organization must obtain Permission from the following organization which has been delegated for copyright clearance by the copyright owner of this publication.

$<$ Except in the USA $>$

Japan Academic Association for Copyright Clearance(JAACC)

41-6 Akasaka 9-chome, Minato-ku, Tokyo 107-0052 Japan

Phone:+81-03-3475-5618 FAX:+81-03-3475-5619 E-mail:jaacc@mtd.biglobe.ne.jp

$<$ In the USA $>$

Copyright Clearance Center, Inc.

222 Rosewood Drive, Danvers, MA 01923 USA

Phone:+1-978-750-8400 FAX:+1-978-750-4744

\section{森林計画学会誌 第 47 巻 第 2 号}

2013 年 (平成 25 年) 12 月 20 日印刷

2013 年（平成 25 年） 12 月 25 日発行

\author{
編集人近藤洋史 \\ 発行人溝上展也 \\ 発 行 所森林計画学会 \\ T 812-8581 福岡県福岡市東区箱崎 6-10- 1 \\ 九州大学農学部森林計画学研究室内 \\ TEL : 092-642-2866 \\ E-mail : jsfp_pr@ffpri.affrc.go.jp \\ 印 刷 所 シモダ印刷株式会社 \\ 干 862-0951 熊本県熊本市中央区上水前寺 2丁目 16-16 \\ TEL : 096-383-5512
}

